\title{
Cytoplasmic Expression of Ribozyme In Zebrafish Using a T7 Autogene System
}

Kelly Walker ${ }^{1,2}$, Yuefeng $\mathrm{Xie}^{3}$, Yunsheng $\mathrm{Li}^{1}{ }^{1}$,
Qin Zhu', Wenlian $\mathrm{Xu}^{4}$, Thomas E. Wagner,
and Xiaozhuo Chen
${ }^{1,2,5 *}$

${ }^{1}$ Edison Biotechnology Institute, 109 Konneker Laboratories, Ohio University, Athens, OH 45701, USA

${ }^{2}$ Molecular and Cellular Biology Program, Ohio University, Athens, $\mathrm{OH}$ 45701, USA

${ }^{3}$ Genetic Therapy Inc., 938 Clopper Road, Gaithersburg, MD 20878, USA

${ }^{4}$ Department of Biological Sciences, Tsinghua University, Beijing 10084, China

${ }^{5}$ Department of Chemictry and Biochemistry,

Ohio University, Athens, OH 45701, USA

\begin{abstract}
A cytoplasmic ribozyme expression system, based on codelivery of a ribozyme vector, a T7 autogene vector, and T7 RNA polymerase (RNAP), has been developed and used to generate a specific phenotype in zebrafish by targeting a no tail (nt) mRNA. The expression of the no tail ribozyme sequence is under the control of a tandem of two promoters: The T7 promoter and an adenoviral va 1 (pol III) promoter. The coinjection of the ribozyme vector pT7vaRz, the T7 autogene vector PT7T7, and the T7 RNAP resulted in rapid synthesis of the ribozyme against the $n t$ mRNA in the cytoplasm of the injected zebrafish embryos, generating no tail phenotypes in up to $10-20 \%$ of the injected embryos. The phenotypic change rates have been found to be related to the concentrations of the plasmid vectors and T7 RNAP injected and to the ratios of the three injected components. This cytoplasmic ribozyme expression system may be useful for efficiently targeting other mRNA and for various biomedical applications. These potential applications may include rapid identification of biological functions of novel genes from zebrafish and humans based on partial gene sequence information and gene therapy of genetic and acquired diseases.
\end{abstract}

\section{Introduction}

Ribozymes have been used extensively in biological research and biomedical applications in cancer (1-4), AIDS (5-7), and in the elucidation of the molecular mechanisms of developmental/regulatory pathways $(8,9)$ and the roles of certain proteins in these pathways $(10,11)$. We have recently used a hammerhead ribozyme expressed by a T7 autogene system to target the $\mathrm{ntl}$ gene in zebrafish, and for the first time have successfully demonstrated the no tail phenotype in the manipulated wild-type zebrafish embryos resulting from the reduction of the $n t / m R N A(12)$.
There are several unique features associated with this T7 autogene ribozyme system:

- T7 RNAP is coinjected with the ribozyme vector directly into the cytoplasm of the fertilized zebrafish eggs to jump start the synthesis of both the ribozyme and the T7 RNAP. Since the T7 RNAP is a bacterial phage enzyme and is found to be localized only in the cytoplasm of eukaryotic cells $(13,14)$, the ribozyme synthesis by the T7 autogene system is also localized in the cytoplasm, instead of in the nucleus as with most other vectors.

- Because of the cytoplasmic localization of the vector and T7 RNA polymerase, the ribozyme synthesis occurs immediately after the vector and T7 RNAP are coinjected into the zebrafish eggs. There are no delays such as those associated with nuclear membrane entry and protein synthesis required by the nuclear vectors.

- In the ribozyme vector, in addition to the T7 promoter, there is also a va (pol III) promoter that is able to further increase the ribozyme synthesis. These three features, cytoplasmic localization, rapid ribozyme synthesis, and high levels of the ribozyme synthesis may be the most important factors that contributed to the efficiency of the T7 autogene/ribozyme expression system and to phenotype generation.

In this study, the solutions containing either the pT7vaRz vector, the PT7T7 vector or CMV promoter-driving T7 RNAP expressing vectors, with or without the T7 RNAP, mixed in different ratios, were injected into the fertilized zebrafish eggs to evaluate the differential contributions of the components of the injection solution in the generation of the no tail phenotype.

\section{Materials and Methods}

\section{Plasmid DNA Vectors and Cells}

Plasmid pT7T7 (Figure 1A, EMBL accession number: Z32692), which contains a T7 autogene, was constructed as previously described (14). The plasmid pT7-2 was made by deleting the encephalomyocarditis virus internal ribosome entry site (EMC-IRES) sequence from plasmid pTM-1 (15). The pGvaRz plasmids were constructed by insertion of a DNA fragment encoding the no tail ribozyme molecule with different flanking sequences into the Sal I/ Pst I sites of the pGvaL vector (a gift of Dr. Kay. 16). In the pGvaRz plasmid, the expression of the ribozyme was under the control of a human adenovirus type 2-associated vaRNA I (va) gene promoter, which is an RNA polymerase III promoter. The pT7vaRz plasmids were constructed by insertion of the $500 \mathrm{bp} \mathrm{Xba} \mathrm{I/Sac} \mathrm{I} \mathrm{fragment} \mathrm{from} \mathrm{pGvaRz,}$ which contains the va promoter expression cassette and the ribozyme sequence, into the EcoR I/Sac I sites of the pT7-2 plasmid vector. In pT7vaRz plasmids, the ribozyme sequence is driven by both a T7 promoter and a va 
A.
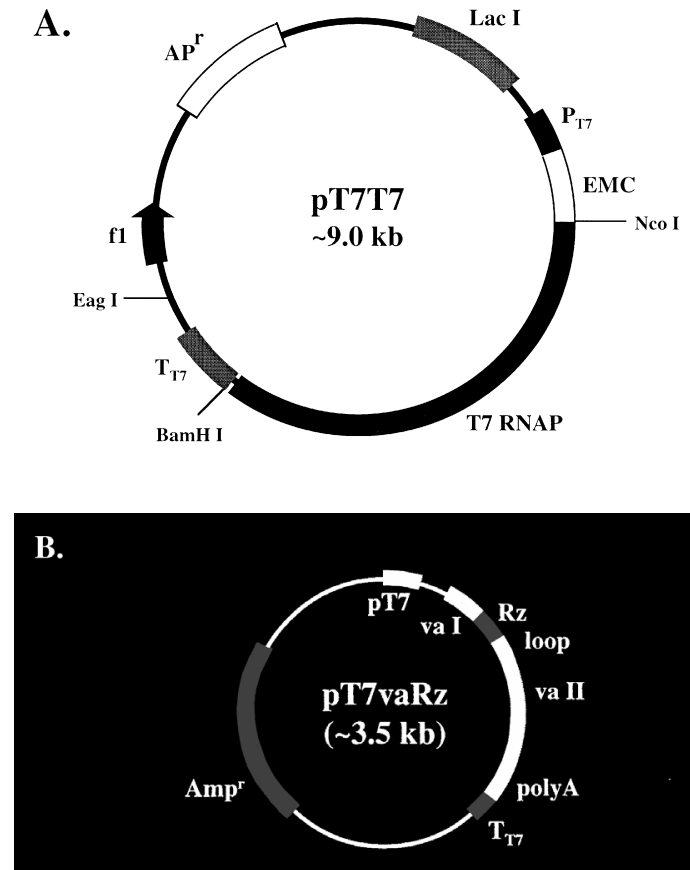

C.

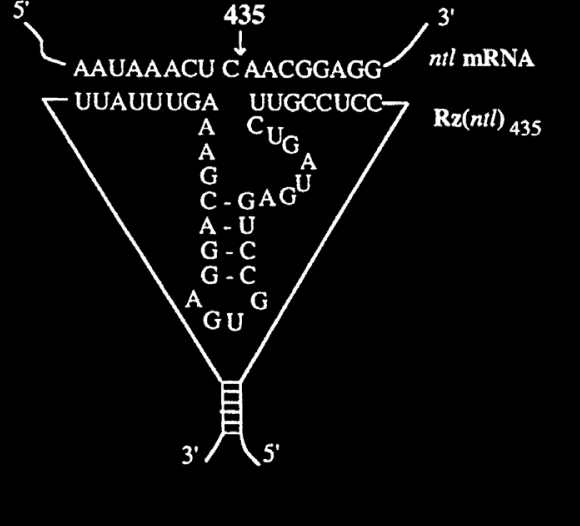

Figure 1. T7 autogene vector $\mathrm{pT7T7}$, ribozyme vector $\mathrm{pT7vaRz}$, and no tail ribozyme with its $n t /$ mRNA target. A. pT7T7 (14). PT7 = T7 promoter, T7 RNAP $=$ the T7 RNAP gene, TT7 = T7 transcription termination sequence, $\mathrm{EMC}=\mathrm{EMC}$-IRES as described in the Materials and Methods. B. pT7vaRz (12). C. The secondary structure of the no tail ribozyme and its ntl mRNA substrate.

promoter (Figure 1B). To compare cytoplasmic and nuclear ribozymes, a pCMVT7 vector with a T7 RNAP gene driven by a CMV promoter, and a pCMVT7nls vector with a T7 RNAP gene carrying a nuclear localization signal sequence (T7nls) also driven by a CMV promoter, were constructed and used side by side in zebrafish egg injections with the pT7vaRz vector. The T7nls gene, which was made by insertion of an SV40 nuclear localization signal (nls) sequence into the T7 RNAP gene, encodes a protein that has been shown to be localized in the nucleus of the transfected mammalian cells and to be active as an RNAP (unpublished result).

Bacterial Escherichia colistrain HMS174(DE3) pLysE was used to propagate the pT7T7 plasmid (14), and E. coli $\mathrm{DH} 5 \alpha$ was used as the host cell for all other plasmids. Plasmid DNA was prepared by using a Qiagen Plasmid Maxi Kit (Qiagen Inc.).

\section{Zebrafish Maintenance and Microinjection of Fertilized Zebrafish Eggs}

Zebrafish were maintained in our zebrafish facility, which has a day-night light cycle controlled by an automatic timer (15 hours light/9 hours dark). Fertilized zebrafish eggs were produced and harvested as described by Westerfield (17). To obtain fertilized zebrafish eggs at the one-cell stage, the breeding tanks were siphoned every 15 minutes starting from the first spawn. After the egg collection, the chorion of the eggs was removed by incubation with DMEM medium containing $0.125 \%$ trypsin (Gibco BRL, $1: 300$ ) at $28.5^{\circ} \mathrm{C}$ for 3-5 minutes, as previously described (18).

Zebrafish egg microinjection was performed under 4080X magnification using a dissecting microscope and a homemade micromanipulator, which holds an injection pipette and can be moved in a three-dimensional manner. Approximately $2 \mathrm{nl}$ of DNA solution was microinjected into the cytoplasm of the dechorionated fertilized eggs at the one-cell stage, as previously described (19). Injection of a volume larger than $2 \mathrm{nl}$ would result in a much lower survival rate and a much higher rate of developmental abnormalities in the injected embryos. Zebrafish embryos develop rapidly at room temperature, therefore the time window for the microinjection is less than 15 minutes. In our lab, about 150 eggs can be injected in such a period of time. The manipulated embryos were kept at $28.5^{\circ} \mathrm{C}$ in the Embryo Medium (17) containing $100 \mu \mathrm{g} / \mathrm{ml}$ ampicillin in an agarose bottomed petri dish.

DNA solutions for microinjection were made by diluting plasmid DNA in a low concentration ST solution (25 mM $\mathrm{NaCl}, 2.5 \mathrm{mM}$ Tris.Cl, pH 7.0). When the T7 RNAP was included, the DNA solution was made by mixing $1 \mu \mathrm{l}$ of T7 RNAP (50 units/ $\mu$ l, New England BioLabs) with $2 \mu$ of pT7T7 plasmid DNA $(100 \mu \mathrm{g} / \mathrm{ml})$ and $18 \mu \mathrm{l}$ of pT7vaRz plasmid DNA (100 $\mu \mathrm{g} / \mathrm{ml})$. A plasmid DNA concentration of $100 \mu \mathrm{g} / \mathrm{ml}$ was selected to achieve the maximum transgene expression levels possible while maintaining reasonable survival rates for the manipulated embryos. At this concentration, about $10^{7}$ copies of pT7vaRz plasmids $(3.53 \mathrm{~kb})$ were injected into each egg. Microinjection of higher concentrations of DNA resulted in significant nonspecific damages to the manipulated embryos and in much lower survival rates. Only the circular form of plasmid DNA was used in this study, because it was believed that the circular form of DNA can persist and be expressed in the fish embryos longer than the linear form $(19,20)$.

\section{Design of Hammerhead Ribozymes}

The RNAdraw program (21) was used to determine the secondary structure of the $\mathrm{ntl}$ mRNA molecule. The program was directly downloaded from the internet (http:/ /mango.mef.ki.se/ ole/rnadraw/rnadraw.html). The sequence of ntl cDNA, with a total length of $2237 \mathrm{bp}$ (22), was input into the RNAdraw program and the secondary structure of the ntl mRNA at $28.5^{\circ} \mathrm{C}$ was computed. The secondary structure of $n t I$ mRNA predicted by the RNAdraw program contains a total of 160 loops. 
A

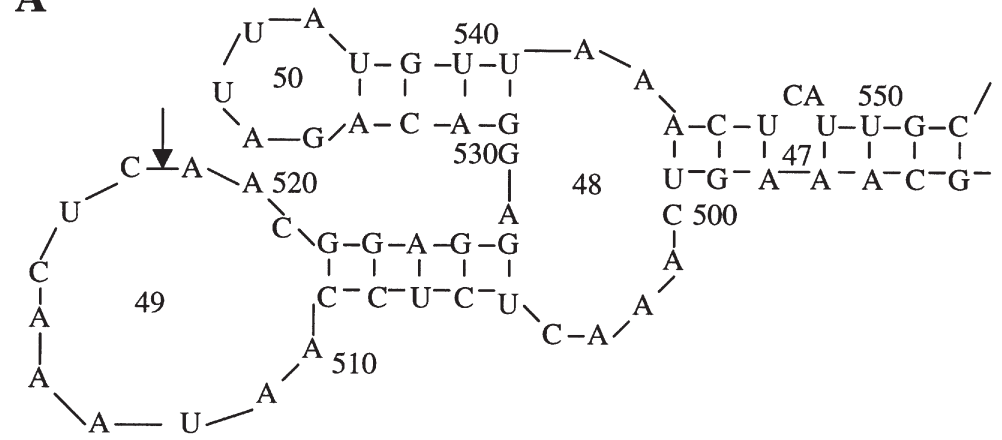

B

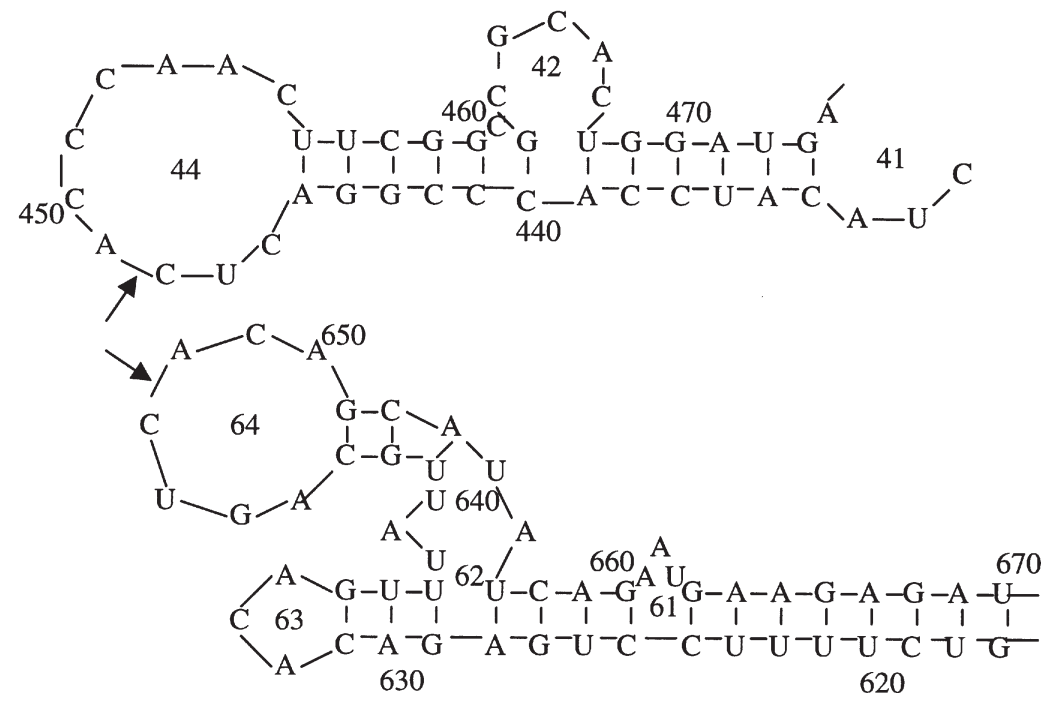

Figure 2. The computer-predicted secondary structures of the zebrafish $n t l$ mRNA in the regions surrounding the potential cleavage sites $\mathrm{CUC}_{365}, \mathrm{CUC}_{435}$ and $\mathrm{GUC}_{564}$. The nucleotides in the loop regions are numbered as their respective positions in the $2237 \mathrm{bp} \mathrm{ntl}$ cDNA sequence (22). A. CUC 435 site (518 in the $n t / c D N A), B . C_{365}$ site (448 in the $n t /$ cDNA), and C. GUC ${ }_{564}$ site (647 in the $n t$ cDNA). Arrows indicate ribozyme cleavage sites.
Based on the predicted ntl mRNA secondary structure, all the GUC sites and CUC sites in the loops and unpaired regions were selected for further analysis, because it has been shown that the hammerhead ribozymes cleave their substrates at GUC and CUC sites at much higher frequencies (23). To ensure that the ribozyme-cleaved $\mathrm{ntl}$ mRNA does not yield a truncated polypeptide with full or partial biological functions, the selected target sites should be located $3^{\prime}$ of, but most $5^{\prime}$ proximal to, the translation start codon AUG of the targeted mRNA.

Three such accessible sites in the predicted ntl mRNA secondary structure were selected for the ribozyme design. The first target is a CUC site at position 435 of the ntI mRNA (518 at the $\mathrm{ntl}$ cDNA), located on a 14 nucleotide (nt) loop, loop 49 (Figure 2A). The second target is a CUC site at position 365 of the ntl mRNA (448 at the ntl cDNA), located on a $12 \mathrm{nt}$ loop, loop 44 (Figure 2B). The third target is a GUC site at position 564 of the ntl mRNA (647 at the ntl cDNA), located on a 9 nt loop, loop 64 (Figure 2C). The ribozyme-targeted sequences surrounding these three sites are 5'- AAU AAA CUC AACGGA GG -5, 5'- CCC GGA CUC ACC CAA CU -3', and 5'- AUU GCA GUC ACA GCA UA -3', respectively, when a hammerhead ribozyme with 8 nts on either binding arm was used.

Three hammerhead ribozymes were designed to target these three selected sites. A pair of complementary oligodeoxynucleotides was synthesized (Oligo Therapeutic Inc.) for each hammerhead ribozyme according to its targeted sequence on the ntl mRNA. The oligos of each pair were annealed to form a double-stranded DNA fragment with a Sal I half-site on its 5 ' terminus and a Pstl half-site on its $3^{\prime}$ terminus. This fragment was then cloned into the Sall/Pstl sites of the pGvaL vector as described above.

For the hammerhead ribozyme targeting the CUC435 site, the sequence of oligo 1 (47 mer) was: 5'TCGACCTCCG TTCTGATGAG TCCGTGAGGA CGAAAGTTTA TTCTGCA-3', and the sequence of oligo 2 (39 mer) was: 5'- GAATAAACTT TCGTCCTCAC GGACTCATCA GAACGGAGG-3'.

For the hammerhead ribozyme targeting the CUC365 site, the sequence of oligo 1 (48 mer) was: 5'TCGACAGTTG GGTCTGATGA GTCCGTGAGG ACGAAAGTCC GGGCTGCA-3', and the sequence of oligo 2 (40 mer) was: 5'- GCCCGGACTT TCGTCCTCAC GGACTCATCA GACCCAACTG-3'.

For the hammerhead ribozyme targeting the GUC564 site, the sequence of oligo 1 (48 mer) was: 5'TCGACTATGC TGTCTGATGA GTCCGTGAGG ACGAAACTGC AATCTGCA-3', and the sequence of oligo 2 (40 mer) was: 5'- GATTGCAGTT TCGTCCTCAC GGACTCATCA GACAGCATAG-3'.

\section{Northern Blot Analysis}

The total RNA from the injected or uninjected control zebrafish embryos at different developmental stages was isolated using the RNAzol method (24). Typically, 15 - 100 $\mu \mathrm{g}$ of total RNA can be isolated from 30 to 100 eggs by 
Table 1. No Tail Phenotypes Generated by Ribozymes Synthesized by Cytoplasmic or Nuclear T7 RNA Polymerase

\begin{tabular}{ll}
\hline Injection solution & No tail phenotype \\
\hline pT7T7 + pT7vaRz + T7 RNAP $(1: 18: 1)^{1}$ & $+++++^{2}$ \\
pCMVT7 + pT7vaRz (2:17) & +++ \\
pCMVT7nls + pT7vaRz (2:17) & ++ \\
pT7vaRz & ++ \\
\hline
\end{tabular}

Two nanoliters of injection solution were injected into each fertilized egg. The numbers in parentheses represent the volumes (in $\mu \mathrm{l})$ of each corresponding component in the injection solution.

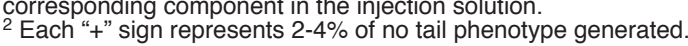

using $400 \mu \mathrm{l}$ of RNAzol solution and $50 \mu \mathrm{l}$ of chloroform in a $1.5 \mathrm{ml}$ microfuge tube. Northern blotting analyses were performed by using a NorthernMax Kit (Ambion). Usually, 8-10 $\mu \mathrm{g}$ of total RNA from each sample was used in the Northern blot analysis. A 900 bp ntl cDNA fragment (1131012) was amplified from the total RNA isolated from 24 hour zebrafish embryos by a reverse transcriptase-PCR (RT-PCR). This fragment was used as the ntl probe in the Northern blotting analysis after being labeled with ${ }^{32} \mathrm{P}$ using a Random Primered DNA Labeling Kit (Boehringer Mannheim).

\section{Phenotype Observation of Zebrafish Embryos}

The early stage of embryonic development of the injected zebrafish eggs was monitored at predetermined time intervals under a dissecting microscope. The uninjected control embryos were compared side by side with the injected embryos at the same stage to help identify phenotypic changes in the manipulated embryos. Whenever a phenotypic change was observed, the embryo was photographed using a camera attached to the dissecting microscope, and the frequency of phenotypic change in each group was recorded and analyzed statistically. When photographing the zebrafish embryos
Table 2. No Tail Phenotypes Generated by Different Ratios of Injection Solution Components

\begin{tabular}{ll}
\hline Injection solution & No tail phenotype \\
\hline pT7T7 + pT7vaRz + T7 RNAP $(1: 18: 1)$ & ++++ \\
pT7vaRz & ++ \\
pT7T7 + pT7vaRz $(2: 18)$ & ++ \\
pT7vaRz + T7 RNAP $(19: 1)$ & ++++ \\
pT7T7 + pT7vaRz + T7 RNAP $(4: 15: 1)$ & ++++ \\
pT7T7 + pT7vaRz + T7 RNAP $(5: 13: 2)$ & ++++ \\
\hline
\end{tabular}

older than 24 hours, which were mobile and constantly moving, the embryos were kept in a $15 \mathrm{mg} / 100 \mathrm{ml}$ MS222 solution (methanesulfonate salt) to maintain the fries in an anaesthetized state.

\section{Results and Discussion}

Three targets on the $n t /$ mRNA were selected (Figure 2) and three ribozymes against these three targets were tested (12). Only one ribozyme, targeting the $\mathrm{CUC}_{435}$ site, was found to be effective in generating no tail phenotypes (Figure 2A, Figure 3,12). Although the reason for the differential effectiveness among the three ribozymes is presently unknown, the location and size of the loop harboring the $\mathrm{CUC}_{435}$ site on the three dimensional structure of the $n t / \mathrm{mRNA}$ are suspected to be involved in the effective targeting. Among the three target sites, the $\mathrm{CUC}_{435}$ site is the one located in the largest loop (14nt, Figure 2A), which may allow this target sequence to be the most accessible to the ribozyme molecule.

It has been found that, under the injection conditions specified, $10-20 \%$ of the injected embryos develop into no tail phenotypes (Table 1 and Table 2 ). The total amount of pT7vaRz, pT7T7, and T7 RNAP injected into a zebrafish

\section{A}

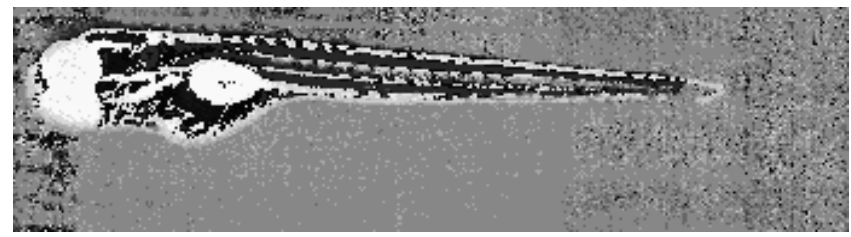

B
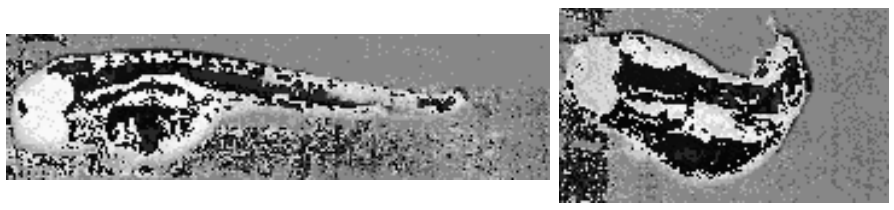

C

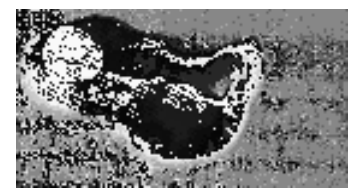

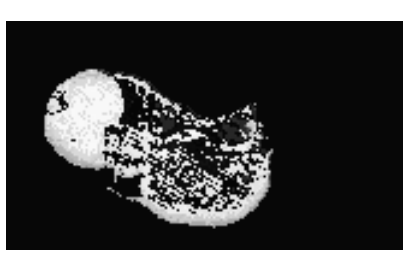

Figure 3. No tail phenotypes generated from the zebrafish embryos injected with pT7vaRz plus PT7T7 plus T7 RNAP. Zebrafish embryos were injected at time zero (the beginning of fertilization) and photographed $96 \mathrm{hrs}$ after injections. A, normal uninjected zebrafish embryo; B, partial no tail phenotypes generated by the injections; $\mathrm{C}$, full no tail phenotype generated by the injection; D, a homozygous no tail mutant (ntb ${ }^{\text {b195 }}$ ) embryo (12). 
egg also greatly affects the percentage of the phenotypic change in the injected embryos. The more DNA + T7 RNAP injected, the higher the percentage of the phenotypic change (unpublished observation). However, nonspecific, injection-related developmental abnormalities and embryo death in the injected embryos also significantly increase if the injection concentration increases beyond certain levels. Thus, it is recommended to determine experimentally the maximal and optimal injection concentrations. In addition, noninjected and injected controls should always be included in every injection experiment to distinguish the specific phenotype change from the nonspecific ones.

To ascertain if the phenotype observed was ntl-specific and if the phenotype could be objectively scored, a blind injection study was performed. Nt/ ribozyme-producing DNA and control DNA were prepared in microfuge tubes and labeled numerically. The contents of each tube were unknown to the microinjectionist. Following injections, an examiner who knew the injected groups by number only was asked to distinguish the phenotypes of the $n t l$ knockdown group from its control groups. This experiment was repeated three times with randomized sample labeling and the phenotype examiner correctly identified the $n t$ knockdown group and control groups in all three trials, demonstrating that the $n t l$ knockdown phenotype can be reproducibly generated and that it can be objectively identified in comparison to its control groups. While the uninjected control groups occasionally show background levels of $n t$-like phenotypes, the distinctive developmental pathway that leads to their morphological similarity does not involve degeneration of posterior tissue as seen in the true no tail phenotype, allowing them to be reliably discriminated from the $n t l$ knockdown phenotype. Furthermore, these $n t$-like phenotypes resemble more closely the partial no tail phenotype, which can be easily distinguished from the high percentages of the full no tail phenotype consistently seen in the $n t /$ ribozyme-producing group.

Injections of $\mathrm{pT7vaRz}$ alone were sufficient to generate some no tail phenotypes (Table 1 and Table 2), suggesting that the va promoter is active at the early developmental stage in zebrafish. A Northern blot analysis on the RNA isolated from the injected fish embryos should be able to confirm this, and a primer extension study should be able to determine the differential contributions of the T7 and the va promoters to the ribozyme pool.

There is experimental evidence to suggest that the cytoplasmic localization of the T7-derived $n t /$ ribozyme may be very important for the phenotype generation. Coinjections of pT7vaRz with pCMVT7nls, a CMV promoter-driven nuclear T7 RNAP, did not further increase the rates in no tail phenotype generation in the injected zebrafish embryos than did the pT7vaRz alone (Table 2), whereas the addition of pCMVT7 to pT7vaRz did improve the rates (Table 1). Although the PCMVT7 is somewhat effective, it is not sufficient itself to replace PT7T7 and T7 RNAP in generating no tail phenotypes (Table 1).

These results suggest that the cytoplasmically synthesized ribozyme may be more effective than the nuclearly generated ribozyme in targeting and cleaving the $n t /$ mRNA. However, it is not clear at this moment whether the significant decrease in no tail phenotype change, generated by injecting pCMVT7nls or PCMVT7 replacing pT7T7, was caused by the nuclear localization of the T7 RNAP (and the consequent nuclear localization of the T7nls-synthesized $n t /$ ribozyme) or by slower and lower ribozyme production due to the CMV promoter, or the combination of both. These different possibilities are currently being investigated.

Cytoplasmic synthesis and localization of the ribozyme $(12,25-27)$, as well as the rapidity and high levels of ribozyme synthesis, are likely to be the most important factors that contributed to no tail phenotypes in the injected zebrafish embryos (12). The speed of the ribozyme synthesis can be further adjusted by changing the ratios of pT7vaRz, pT7T7, and T7 RNAP (Table 2). Because the synthesis of pT7T7-derived T7 RNAP requires both transcription and translation processes, the speed of T7 RNAP synthesis is more easily altered by changing the concentration of the coinjected T7 RNAP than by increasing the coinjected PT7T7. However, the role of the PT7T7 autogene may become more important for those gene targets whose expressions are not as early as the $n t /$ gene. Under those situations, it may be more effective to change the concentration of the PT7T7 autogene than the T7 RNAP, since the expression of the pT7T7 is more persistent than the enzymatic activity of the injected T7 RNAP.

It has been found that the no tail phenotypic change may take 2 to 3 days to complete (Figure 3 ). It is recommended that injected embryos be monitored for at least 3 days starting $20 \mathrm{hrs}$ after injection. Although the no tail phenotype observed in the injected embryos was identical to those in the no tail mutant (nt| ${ }^{\mathrm{b} 160}$ or nt| $\left.{ }^{\mathrm{b} 195}\right)$ at 3 days post fertilization, the appearance of no tailphenotype in the injected embryos was always later than the no tail mutants. Also, the shrinkage of the tail in the first two days in the injected embryos was not as severe as in the no tail mutant embryos. This can be explained as the incomplete block of $n t /$ protein synthesis in the injected embryos, because it has been found that a transplant of a small number of cells expressing the $n t l$ gene into the homozygous no tail mutant embryos is sufficient to rescue the embryos (28). It is believed that this ribozyme mediated gene knockdown strategy for gene function determination would work more effectively with dominant genes than recessive ones in producing detectable phenotypic changes, because it works fairly effectively in targeting a dominant recessive gene such as $n t /$ gene and in giving a visible phenotypic change.

Two other gene knockdown approaches have been used in zebrafish: injection of double-stranded RNA (dsRNA) and morpholino-oligonucleotides. Although numerous papers reported phenotype generations by dsRNA, two recent findings showed that so many nonspecific effects were produced by dsRNA injections that researchers were unable to distinguish the zebrafish population generated by target-specific dsRNA from those generated from non-specific dsRNA injections in blind studies (29, 30). A very recent publication showed effective targeted gene knockdown in zebrafish by morpholinooligonucleotides on multiple genes (31). Because of potential differences in mode of inhibition, level of inhibition, time and duration of inhibition, target specificity, cytotoxicity of the knockdown molecules, and cost, the ribozyme- 
mediated approach may provide an attractive alternative to the morpholino-oligonucleotide approach.

This and previous studies have demonstrated that the T7 autogene-derived cytoplasmic ribozymes can be a very powerful tool for the determination of biological functions of zebrafish genes, such as $n t l$, as well as for genes from other species, including humans. One significant advantage of this ribozyme-mediated gene knockdown approach is that only partial gene sequences are required for targeting and identification of gene functions if the complete gene sequence is not available. In addition, zebrafish offers an attractive alternative animal model with several distinctive features for studying developmental genetics: rapid embryonic development for fast turnover rates, oviparous and transparent embryos for convenient observation, as well as relatively low maintenance cost compared to other mammalian animal models. Therefore, this approach, the T7 autogene-derived ribozyme coupled with the zebrafish model, may significantly accelerate the elucidation of the biological functions of newly discovered genes.

\section{References}

1. Wiechen, K., Zimmer, C., and Dietel, M. 1998. Selection of a high activity c-erbB-2 ribozyme using a fusion gene of c-erbB-2 and the enhanced green fluorescent protein. Cancer Gene Therapy. 5: 4551.

2. Matsushita, H., Kizaki, M., Kobayashi, H., Ueno, H., Muto, A., Takayama, N., Awaya, N., Kinjo, K., Hattori, Y., and Ikeda, Y. 1998. Restoration of retinoid sensitivity by MDR1 ribozymes in retinoic acidresistant myeloid leukemic cells. Blood. 91: 2452-2458.

3. Dorai, T., Goluboff, E.T., Olson, C.A., and Buttyan, R. 1998 Development of a hammerhead ribozyme against BCL-2. II. Ribozyme treatment sensitizes hormone-resistant prostate cancer cells to apoptotic agents. Anticancer Research. 17: 3307-3312.

4. Snyder, D.S., Wu, Y., McMahon, R., Yu, L., Rossi, J.J., and Forman, S.J. 1997. Ribozyme-mediated inhibition of a Philadelphia chromosome-positive acute lymphoblastic leukemia cell line expressing the p190 bcr-abl oncogene. Biol. of Blood and Marrow Transplantation. 3: 179-186.

5. Dropulic, B., Hermankova, M., and Pitha, P.M. 1996. A conditionally replicating HIV-1 vector interferes with wild-type HIV-1 replication and spread. Proc. Natl. Acad. Sci. USA. 93: 11103-11108.

6. Lee, C.G., Jeang, K.T., Martin, M.A., Pastan, I., and Gottesman, M.M 1997. Efficient long-term coexpression of a hammerhead ribozyme targeted to the U5 region of HIV-1 LTR by linkage to the multidrugresistance gene. Antisense and Nucleic Acid Drug Development. 7 511-522.

7. Ramezani, A., Ding, S.F., and Joshi, S. 1997. Inhibition of HIV-1 replication by retroviral vectors expressing monomeric and multimeric hammerhead ribozymes. Gene Therapy. 4: 861-867.

8. Sokol, D.L., and Murray, J.D. 1996. Antisense and ribozyme constructs in transgenic animals. Transgenic Res. 5: 363-371.

9. Hermann, T., and Westhof, E. 1998. RNA as a drug target: Chemical, modelling, and evolutionary tools. Current Opinion in Biotech. 9: 6673.

10. Czubayko, F., Liaudet-Coopman, E.D., Aigner, A., Tuveson, A.T., Berchem, G.J., and Wellstein, A. 1997. A secreted FGF-binding protein can serve as the angiogenic switch in human cancer. Nature Medicine. 3: $1137-1140$.

11. Gu, J. L., Nadler, J., and Rossi, J. 1997. Use of a hammerhead ribozyme with cationic liposomes to reduce leukocyte type 12 lipoxygenase expression in vascular smooth muscle. Mol. Cellul. Biochem. 172: 47-57.

12. Xie, Y., Chen, X., and Wagner, T. 1997. A ribozyme-mediated, gene "knockdown" strategy for the identification of gene function in zebrafish. Proc. Natl. Acad. Sci. USA. 94: 13777-13781.

13. Dunn, J.J., Krippl, B., Bernstein, K., Westphal, H., and Studier, F.W. 1988. Targeting bacteriophage T7 RNA polymerase to the mammalian cell nucleus. Gene. 68: 259-266.

14. Chen, X., Li, Y., Xiong, K., and Wagner, T. 1994. A self-initiating eukaryotic transient gene expression system based on cotransfection of bacteriophage T7 RNA polymerase and DNA vectors containing a T7 autogene. Nucleic Acids Res. 22: 2114-2120.
15. Moss, B., Elroy-Stein, O., Mizukami, T., Alexander, W.A., and Fuerst, T.R. 1990. New mammalian expression vectors. Nature. 348: 91-92.

16. Lieber, A., and Kay, M.A. 1996. Adenovirus-mediated expression of ribozyme in mice. J. Virol. 70: 3153-3158.

17. Westerfield, M. 1993. The zebrafish book: A guide for the laboratory use of zebrafish (Brachidanio rerio). Eugene: University of Oregon Press.

18. Xie, Y., Liu, D., Zou, J., Li, G., and Zhu, Z. 1989. Novel gene transfer into the fertilized eggs of loach via electroporation. Acta Hydrobiol. Sin. 13: 387-389

19. Zhu, Z., Xu, K., Xie, Y., Li, G., and He, L. 1989. A model of transgenic fish. Sci. Sin. (B) 2: 147-155.

20. Xie, Y., Liu, D., Zou, J., Li, G., and Zhu, Z. 1993. Gene transfer via electroporation in fish. Aquaculture. 111: 207-213.

21. Matzra, O., and Wennborg, A. 1996. RNAdraw: An integrated program for RNA secondary structure calculation and analysis under 32-bit Microsoft Windows. Appl. Bios. 12: 247-249.

22. Schulte-Merker, S., Ho, R.K., Herrmann, B.G., and Nusslein-Volhard, C. 1992. The protein product of the zebrafish homologue of the mouse $\mathrm{T}$ gene is expressed in nuclei of the germ ring and the notochord of the early embryo. Development. 116: 1021-1032.

23. Lieber, A., and Strauss, M. 1995. Selection of efficient cleavage sites in target RNAs by using a ribozyme expression library. Mol. Cellul. Biol. 15: 540-551.

24. Chomczynski, P., and Sacchi, N. 1987. Single-step method of RNA isolation by acid guanidinium thiocyanate-phenol-chloroform extraction. Anal. Biochem. 162: 156-159.

25. Domi, A., Beaud, G., and Favre, A. 1996. Transcripts containing a small anti-HIV hammerhead ribozyme that are active in the cell cytoplasm but inactive in vitro as free RNAs. Biochimie. 78: 654-662.

26. Hormes, R., Homann, M., Oelze, I., Marschall, P., Tabler, M., Eckstein, F., and Sczakiel, G. 1997. The subcellular localization and length of hammerhead ribozymes determine efficacy in human cells. Nucl. Acids. Res. 25: 769-775.

27. Prislei, S., Buonomo, S., Michienzi, A., and Bozzoni, I. 1997. Use of adenoviral VAI small RNA as a carrier for cytoplasmic delivery of ribozyme. RNA. 3: 677-687.

28. Schulte-Merker, S., van Eeden, F.J.M., Halpern, M.E., Kimmel, C.B. and Nusslein-volhard, C. 1994. No tail (ntl) is the zebrafish homologue of the mouse T (Brachyury) gene. Development 120: 1009-1015.

29. Oates, A.C., Bruce, A.E., and Ho, R.K. 2000. Too much interference: Injection of double- stranded RNA has nonspecific effects in the zebrafish embryo. Dev. Biol. 224: 20-28.

30. Zhao, Z., Cao, Y., Li, M., and Meng, A. 2001. Double-stranded RNA injection produces nonspecific defects in zebrafish. Dev. Biol. 229: 215-223.

31. Nasevicius, A. and Ekker, S.C. 2000. Effective targeted gene 'knockdown' in zebrafish. Nature Genetics 26: 216-220. 


\section{Further Reading}

Caister Academic Press is a leading academic publisher of advanced texts in microbiology, molecular biology and medical research. Full details of all our publications at caister.com

- MALDI-TOF Mass Spectrometry in Microbiology Edited by: M Kostrzewa, S Schubert (2016) www.caister.com/malditof

- Aspergillus and Penicillium in the Post-genomic Era Edited by: RP Vries, IB Gelber, MR Andersen (2016) www.caister.com/aspergillus2

- The Bacteriocins: Current Knowledge and Future Prospects Edited by: RL Dorit, SM Roy, MA Riley (2016)

www.caister.com/bacteriocins

- Omics in Plant Disease Resistance Edited by: V Bhadauria (2016) www.caister.com/opd

- Acidophiles: Life in Extremely Acidic Environments Edited by: R Quatrini, DB Johnson (2016) www.caister.com/acidophiles

- Climate Change and Microbial Ecology: Current Research and Future Trend

Edited by: J Marxsen (2016)

www.caister.com/climate

- Biofilms in Bioremediation: Current Research and Emerging Technologies

Edited by: G Lear (2016)

www.caister.com/biorem

- Microalgae: Current Research and Applications Edited by: MN Tsaloglou (2016) www.caister.com/microalgae

- Gas Plasma Sterilization in Microbiology: Theory, Applications, Pitfalls and New Perspectives Edited by: H Shintani, A Sakudo (2016) www.caister.com/gasplasma

- Virus Evolution: Current Research and Future Directions Edited by: SC Weaver, M Denison, M Roossinck, et al. (2016) www.caister.com/virusevol

- Arboviruses: Molecular Biology, Evolution and Control Edited by: N Vasilakis, DJ Gubler (2016) www.caister.com/arbo

- Shigella: Molecular and Cellular Biology Edited by: WD Picking, WL Picking (2016) www.caister.com/shigella

-Aquatic Biofilms: Ecology, Water Quality and Wastewater Treatment

Edited by: AM Romaní, H Guasch, MD Balaguer (2016)

www.caister.com/aquaticbiofilms

- Alphaviruses: Current Biology

Edited by: S Mahalingam, L Herrero, B Herring (2016)

www.caister.com/alpha

- Thermophilic Microorganisms

Edited by: F Li (2015)

www.caister.com/thermophile
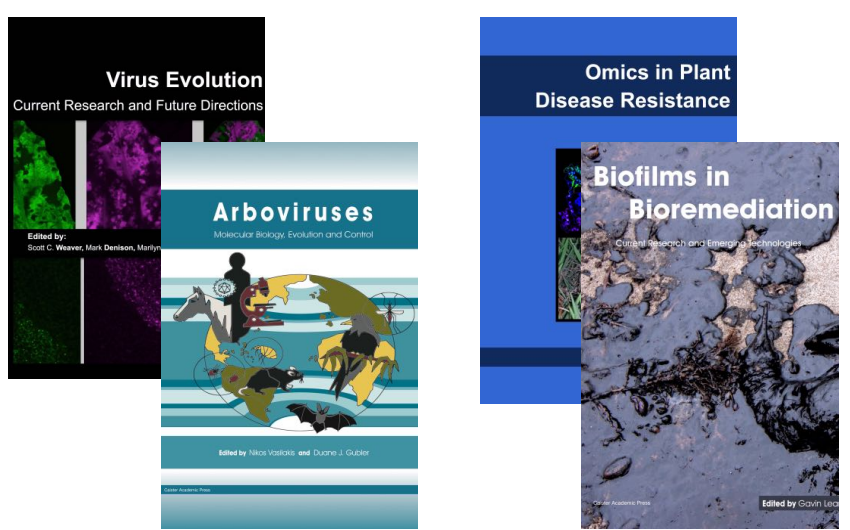
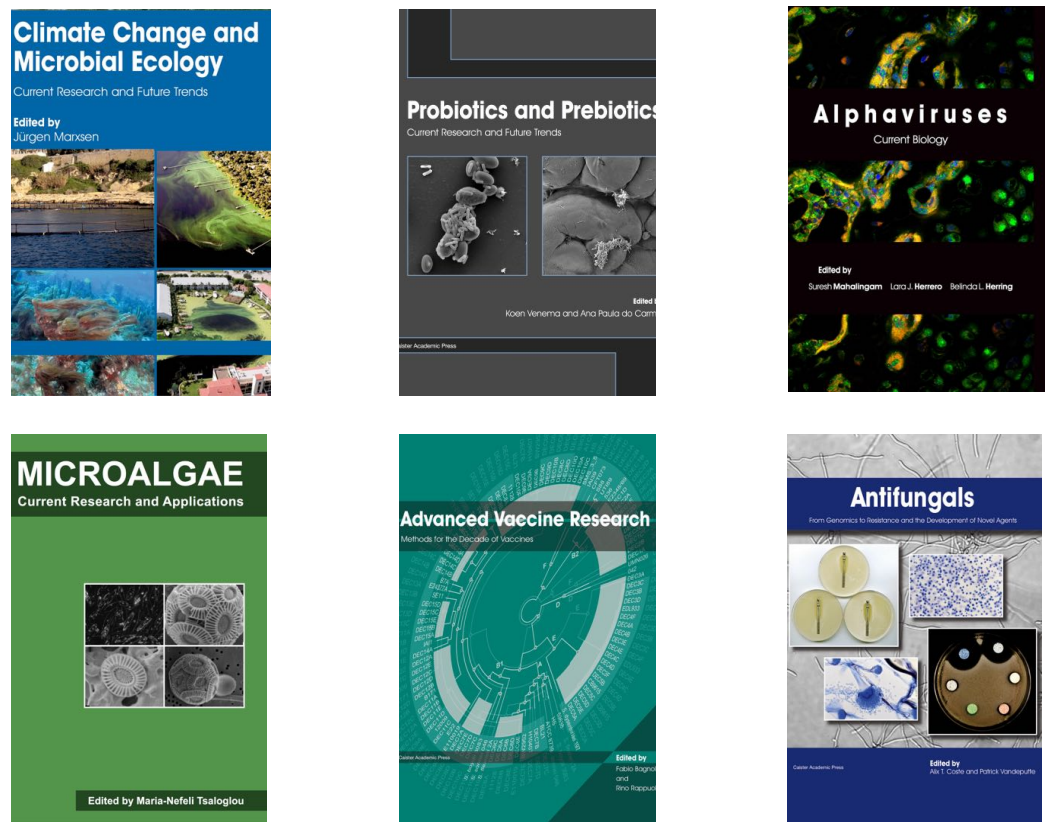

- Flow Cytometry in Microbiology: Technology and Applications Edited by: MG Wilkinson (2015) www.caister.com/flow

- Probiotics and Prebiotics: Current Research and Future Trends Edited by: K Venema, AP Carmo (2015) www.caister.com/probiotics

- Epigenetics: Current Research and Emerging Trends Edited by: BP Chadwick (2015) www.caister.com/epigenetics2015

- Corynebacterium glutamicum: From Systems Biology to Biotechnological Applications

Edited by: A Burkovski (2015)

www.caister.com/cory2

- Advanced Vaccine Research Methods for the Decade of Vaccines

Edited by: F Bagnoli, R Rappuoli (2015)

www.caister.com/vaccines

- Antifungals: From Genomics to Resistance and the Development of Novel Agents

Edited by: AT Coste, P Vandeputte (2015)

www.caister.com/antifungals

- Bacteria-Plant Interactions: Advanced Research and Future Trends Edited by: J Murillo, BA Vinatzer, RW Jackson, et al. (2015) www.caister.com/bacteria-plant

\section{- Aeromonas}

Edited by: J Graf (2015)

www.caister.com/aeromonas

- Antibiotics: Current Innovations and Future Trends

Edited by: S Sánchez, AL Demain (2015)

www.caister.com/antibiotics

- Leishmania: Current Biology and Contro Edited by: S Adak, R Datta (2015) www.caister.com/leish2

- Acanthamoeba: Biology and Pathogenesis (2nd edition) Author: NA Khan (2015)

www.caister.com/acanthamoeba2

- Microarrays: Current Technology, Innovations and Applications Edited by: Z He (2014)

www.caister.com/microarrays2

- Metagenomics of the Microbial Nitrogen Cycle: Theory, Methods and Applications

Edited by: D Marco (2014)

www.caister.com/n2 